\title{
Viability of Candida albicans in different fomites and hospital surfaces under disinfectants and biological fluids influence
}

\author{
Viabilidade de Candida albicans em diferentes fômites e superfícies hospitalares sob influência de \\ desinfetantes e fluidos biológicos
}

Viabilidad de Candida albicans en diferentes fómites y superficies hospitalarias bajo la influencia de desinfectantes y fluidos biológicos

Thayná Ruiz Ferreira

ORCID: https://orcid.org/0000-0001-8120-6841 Universidade do Oeste Paulista, Brasil

E-mail: thayna.ruiz@hotmail.com

Sérgio Marques Costa

ORCID: https://orcid.org/0000-0001-9287-065X Universidade do Oeste Paulista, Brasil

E-mail: marxcosta@gmail.com

Joyce Marinho de Souza

ORCID: https://orcid.org/0000-0003-4405-2534 Universidade do Oeste Paulista, Brasil

E-mail: joycesouza@unoeste.br

Anthony Cesar de Souza Castilho

ORCID: https://orcid.org/0000-0003-1666-7021 Universidade do Oeste Paulista, Brasil E-mail: castilho.anthony@gmail.com

Lizziane Kretli Winkelstroter Eller

ORCID: https://orcid.org/0000-0001-9352-2630 Universidade do Oeste Paulista, Brasil

E-mail: lizzianekretli@gmail.com

Daniela Vanessa Moris

ORCID: https://orcid.org/0000-0002-0267-3589 Universidade do Oeste Paulista, Brasil E-mail: danimoris@gmail.com

Marcus Vinícius Pimenta Rodrigues ORCID: https://orcid.org/0000-0002-3997-369X Universidade do Oeste Paulista, Brasil E-mail: marcusvinicius@unoeste.br

\begin{abstract}
Hospital environment has factors that promote increased infections caused by microorganisms allowing them to remain viable for long periods on surfaces and fomites. The aim of our study was to identify the viability of Candida albicans in hospital environment common surfaces with biological fluids presence and disinfectants. Four surfaces (cotton fabric, synthetic fabric, egg crate foam mattress and, ceramic floor) were contaminated with a strain of Candida albicans ATCC 26790 and with an association of distilled water, blood, saliva and urine. Also, combinations of surfaces and fluids with addition of $70 \%$ alcohol and $2 \%$ sodium hypochlorite were tested. Viability was identified at 1, 3, 7, 14 and 21 days by Colony Forming Units counting. C. albicans presented 14 days viability in hospitals fabrics with absence of liquids and maintained this persistence under influence of distilled water and blood. It also showed low growth with urine addition and there was growth inhibition with $2 \%$ sodium hypochlorite while with $70 \%$ alcohol and blood there was persistence for up to 7 days in synthetic fabric and mattress. The understanding of these yeasts persistence in hospital surfaces and fomites is essential for a better delineation of protocols control the spread and these infections prevention in healthcare environments.
\end{abstract}

Keywords: Candida albicans; Fomites; Cross-infection; Microbial viability.

\section{Resumo}

$\mathrm{O}$ ambiente hospitalar possui fatores que promovem o aumento das infecções causadas por microrganismos, permitindo que permaneçam viáveis por longos períodos em superfícies e fômites. O objetivo do nosso estudo foi identificar a viabilidade de Candida albicans em superfícies comuns de ambiente hospitalar com presença de fluidos biológicos e desinfetantes. Quatro superfícies (tecido de algodão, tecido sintético, colchão de espuma de engradado de ovo e piso de cerâmica) foram contaminadas com uma cepa de Candida albicans ATCC 26790 e com uma associação 
de água destilada, sangue, saliva e urina. Além disso, foram testadas combinações de superfícies e fluidos com adição de álcool 70\% e hipoclorito de sódio 2\%. A viabilidade foi identificada em 1, 3, 7, 14 e 21 dias por contagem de Unidades Formadoras de Colônia. C. albicans apresentou viabilidade de 14 dias em tecidos hospitalares com ausência de líquidos e manteve essa persistência sob influência de água destilada e sangue. Também apresentou baixo crescimento com adição de urina e inibição do crescimento com hipoclorito de sódio $2 \%$ enquanto com álcool $70 \%$ e sangue persistência por até 7 dias em tecido sintético e colchão. O entendimento da persistência dessas leveduras em superfícies hospitalares e fômites é essencial para um melhor delineamento de protocolos de controle de disseminação e prevenção dessas infecções em ambientes de saúde.

Palavras-chave: Candida albicans; Fômites; Infecção hospitalar; Viabilidade microbiana.

\section{Resumen}

El entorno hospitalario cuenta con factores que favorecen el aumento de infecciones provocadas por microorganismos, lo que les permite permanecer viables durante largos periodos en superficies y fómites. El objetivo de nuestro estudio fue identificar la viabilidad de Candida albicans en superficies comunes en un ambiente hospitalario con presencia de fluidos biológicos y desinfectantes. Cuatro superficies (tela de algodón, tela sintética, colchón de espuma tipo caja de huevos y piso de cerámica) fueron contaminadas con una cepa de Candida albicans ATCC 26790 y con una asociación de agua destilada, sangre, saliva y orina. Además, se probaron combinaciones de superficies y fluidos con la adición de $70 \%$ de alcohol y $2 \%$ de hipoclorito de sodio. La viabilidad se identificó a los 1, 3, 7, 14 y 21 días contando las Unidades Formadoras de Colonias. C. albicans mostró viabilidad durante 14 días en tejidos hospitalarios sin líquidos y mantuvo esta persistencia bajo la influencia de agua destilada y sangre. También mostró bajo crecimiento con la adición de orina e inhibición del crecimiento con hipoclorito de sodio al $2 \%$ mientras que con alcohol al 70\% y persistencia de sangre hasta por 7 días en tela sintética y colchón. Comprender la persistencia de estas levaduras en las superficies y fómites hospitalarios es fundamental para un mejor diseño de protocolos de control de la diseminación y prevención de estas infecciones en entornos sanitarios.

Palabras clave: Candida albicans; Fómites; Infección hospitalaria; Viabilidad microbiana.

\section{Introduction}

Candida albicans adhesins secretion and ability to form hyphae contributes to the formation of fungal biofilm (Chen et al., 2020; Mccall et al., 2019, Ponde et al., 2021). It allows the yeast attachment, maintenance and propagation on abiotic surfaces for long periods and thus can make these environments sources for cross-infection in the healthcare environment (Safdar et al., 2019; Viela et al., 2020). This fungi is able to modulate the metabolism in different environmental conditions as variable temperature, $\mathrm{pH}$ and osmolarity, and availability of nutrients (Santos et al., 2018). Those characteristics leads Candida species as the fourth pathogen most commonly isolated in Healthcare-associated infections (HAI) and the second related to Urinary Tract Infections (UTI) associated with catheters (Enoch et al., 2017; Ture and Alp 2018; Chmielarczyk et al., 2021).

Despite information about C. albicans survival on nosocomial microenvironment and its correlation with infection processes have been studied over the years, influence of body fluids and disinfectants efficacy remains unknown. The Brazilian Health Regulatory Agency (ANVISA, 2012), recommended strict procedures to surface disinfection which aim to decrease the counting microorganisms cells number. Facing that, we evaluated the Candida albicans viability on surfaces and fomites common to the hospital environment, under body fluids and disinfectants influence.

\section{Methodology}

Yeast strain, media and culture conditions: strain C. albicans ATCC26790 used in this study belongs to Microbiology and Immunology Research Laboratory stock of University of Western Sao Paulo (UNOESTE). It was kept frozen at $-20^{\circ} \mathrm{C}$ in Nutrient Broth supplemented with $25 \%$ glycerol and $2 \%$ glucose. Reactivation of frozen strain was done by inoculum in Brain Heart Infusion (BHI) broth incubated for $24-48$ hours at $35^{\circ} \mathrm{C}$, followed by seeding agar Sabouraud Dextrose and incubation for 48 hours at $35^{\circ} \mathrm{C}$. Inoculum for surfaces contamination was prepared from microorganism culture in sterile distilled water at a concentration equivalent to 1.0 on McFarland scale (3.0x108 Colony Forming Units / mL).

Surface contamination: procedure was adapted according to Esteves et al., 2015 using the following surfaces commonly found in nosocomial environment: cotton fabric (white), synthetic fabric (blue), egg crate foam mattress (orange) 
and, ceramic floor (white), sampled into $3.0 \mathrm{~cm} 2$ pieces previously washed and autoclaved. Surfaces were placed in sterile Petri dishes and on each was added specific treatments: only fungal inoculum; fungal inoculum associated with sterile distilled water, artificial saliva (dose manipulation of Saliva; Apsen Farmacêutica, São Paulo, Brazil), blood and urine; fungal inoculum associated with disinfectants ( $70 \%$ alcohol and $2 \%$ sodium hypochlorite); and fungal inoculum in association with fluids and disinfectants, all blends being made in 1:1 or 1: 1: 1 concentration (20uL aliquot). Subsequently, Petri dishes containing the samples were incubated at room temperature inside a reserved box. Thus, analyzes were performed after 1, 3, 7, 14 and 21 days.

Cell viability assay: yeast viability and persistence on different surfaces were identified from immersion of the contaminated surfaces in flasks (urine collection bottles) containing BHI broth and then incubated for 48 hours at $35^{\circ} \mathrm{C}$. Then, after homogenization, $100 \mathrm{uL}$ of broth was transferred to tubes with sterile saline solution for serial dilution standardized at 103. Colony Forming Units (CFU) was counted from the lowest dilution (1:1000) plated on Sabouraud Dextrose agar in triplicate and incubated for 48 hours at $35^{\circ} \mathrm{C}$.

Statistical analysis: to test the isolated effect and the interactions effect of the variables: surface, biological fluid and survival time, the data were transformed into logarithm and submitted to the Shapiro-Wilk test to verify normal distribution. Since all data showed normal distribution, main effects (surface, biological fluid or survival time), double interactions (surface vs. biological fluid, tissue vs. survival time and biological fluid vs. survival time) and triple interactions (surface vs biological fluid vs. survival time) were tested by ANOVA and means compared by Tukey-Kramer test. For general understanding, our data were obtained as mean \pm SEM and, the differences were considered significant when $p<0.05$. All analyzes were performed with JMP software (SAS Institute, Cary, NC, USA).

\section{Results}

Candida albicans viability and persistence can be altered $(\mathrm{p}<0.05)$ by the surface composition and modified over the days through the nutrient's availability from the medium (biological fluid). We observed that, in the absence of fluids, $C$. albicans showed better persistent on surfaces with higher moisture retention capacity (egg crate foam mattress, cotton fabric and synthetic fabric) than on those with lower moisture retention capacity (ceramic floor). Viability was observed until 14 days in cotton fiber and synthetic fiber fabrics, 7 days in egg carton mattress and up to 3 days in ceramic tile (Figure 1).

Figure 1. Candida albicans viability over 21 days in absence of fluids on all tested surfaces.

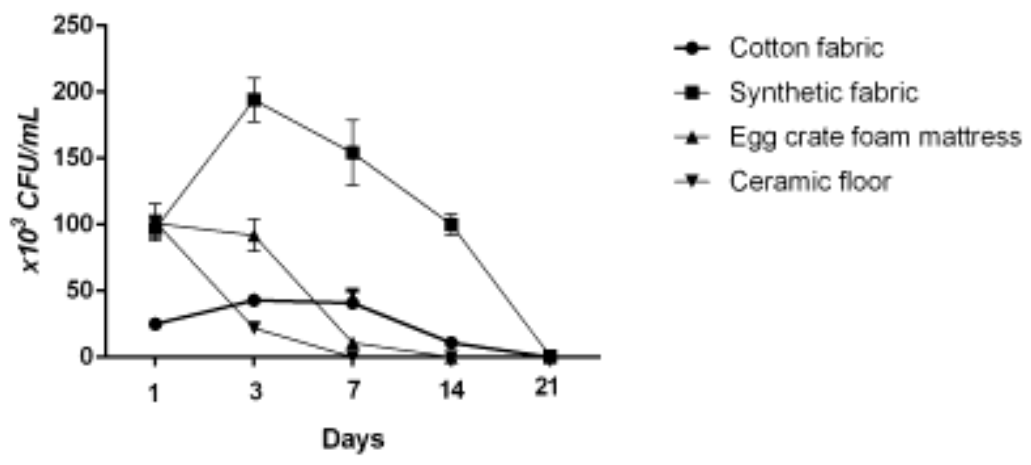

Source: Authors.

C. albicans survival in hospital fabrics remains the same that we found in absence of fluids (14 days) under distilled water addition. Survival rates decreased when considered mattress (three days). No evidence of viability was found on ceramic 
floors with distilled water for this yeast. Regarding manipulated saliva, C. albicans was able to survive for 7 days on synthetic fabric, ceramic floor and mattress, however, in cotton fabric; its survival rate was observed for three days.

In urine, yeast growth was identified for seven days on cotton fiber fabric, three days on synthetic fiber fabric and one day on egg crate foam mattress. Nevertheless, C. albicans showed greater viability with blood and persistence for 14 days in both fabrics and, for seven days on ceramic floor and mattress.

We observed decreased fungal viability on surfaces with less moisture retention (ceramic floor) under influence of all fluids (Figure 2). In comparison between groups with addition and groups without of fluids, we found higher viability of $C$. albicans $(49.65 \mathrm{CFU} / \mathrm{mL})$ in groups without body fluids $(\mathrm{p}=0.0001)$. Followed by blood $(23.80 \mathrm{CFU} / \mathrm{mL})$, saliva $(14.20$ $\mathrm{CFU} / \mathrm{mL})$, urine $(13.35 \mathrm{CFU} / \mathrm{mL})$ and distilled water $(13.10 \mathrm{CFU} / \mathrm{mL})$.

Figure 2. Viability with 21 days dilution for Candida albicans with added distilled water, saliva, blood and urine on all surfaces.
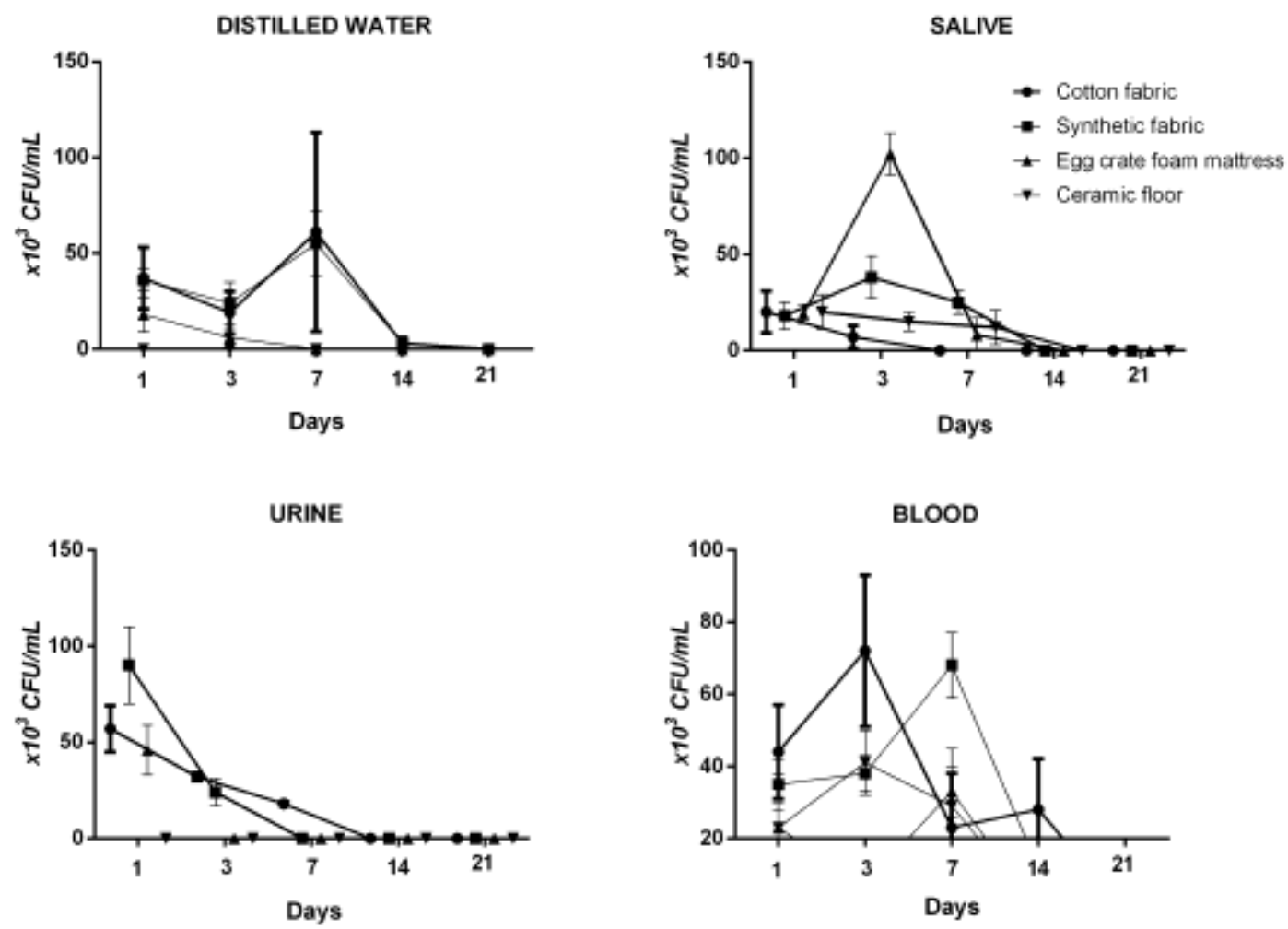

Source: Authors.

Comparison between surfaces showed differences in synthetic fabric and other surfaces analyzed $(p=0.0004)$, averaging $40.44 \mathrm{CFU} / \mathrm{mL}$, cotton 21.64, mattress 18.64 and, floor $10.56 \mathrm{CFU} / \mathrm{mL}$. In addition, synthetic fabric also stands out in comparison with fluids absence and addition ( $\mathrm{p}=0.0096)$, which shows colony recovery in the presence of most fluids for at least seven days.

Use of alcohol $70 \%$ associated with blood fluid allowed C. albicans survival for up seven days in the synthetic fiber tissue and egg crate foam mattress, against 3 days in the ceramic floor. 


\section{Discussion}

We identified $C$. albicans survival for 14 days in all fabrics. Previous studies have shown that $C$. albicans can survive and persist for months on abiotic surfaces (Kramer et al., 2006; Prada et al., 2019). Neely and Orloff, 2001, studied fungi survival of medical importance in fabrics and plastics from hospital environment and identified four days an average survival of in all materials for $C$. albicans, C. tropicalis and C. krusei species. Slightly differing from our data, Patojenlerin et al., 2012 reported persistence of $C$. albicans for up to six days on hospital fabrics with cotton fibers and synthetic fabric (60\% cotton and $40 \%$ polyester) and 12 days in wool and silk. Prolonged natural persistence of $C$. albicans on abiotic surfaces leads it to become reservoirs and continuous sources for cross infection transmission if there is no efficacy in regular preventive cleaning.

Porosity of surface influenced C. albicans survival in this study. In accordance to our findings, Springthorpe et al., 2002 reported Candida species better growth and maintenance of viability on porous tissues. In addition, we observed increasing in colonies number on 7th day in comparison with the survival rates after firsts 24 hours, followed by colony decrease until the 14th day. Porosity might be also related to moisture retention capacity of surface. We found that surfaces with lower moisture retention capacity supplemented with urine presented lower survival rates. While surfaces with higher moisture retention capacity presented a better environment permitting $C$. albicans to survive longer periods. The ability to retain moisture inside creates, observed in egg crate foam mattress for example, makes the microenvironment viable for maintenance of fungal cells. Mitchell et al., 2015 reported that physical characteristics of fabric, surfaces electron charges and, also bacterial cell wall electron charges influence microorganism's fixation. The data found by them are similar to our findings concerning yeast persistence, besides the aid in the yeast fixation caused by its own hyphae production, typical of $C$. albicans.

As an important hospital surface, our study brought ceramic floor and egg crate foam mattress to the evaluation of $C$. albicans viability. No scientific data has presented C. albicans ability to survive on those surfaces. Piedrahita et al., 2017 has detected C. albicans persistence for at least seven days on dry (steel discs) and wet (non-nutrient agar) surfaces. These data are similar ours for egg crate foam mattress and higher in comparison with ceramic floor. Traoré et al., 2002 reported survival period of three days in glass and metal, similar results we found on our study concerning ceramic floor. Those data agree with C. albicans persistence in different surfaces and, our data, support the hypothesis of hospital surfaces are a relevant transmission source.

Our results indicated that saliva addition decreased $C$. albicans survival in comparison with distilled water. On the other hand, using similar methodology with medical interest bacteria, Esteves et al., 2015 found bacteria viability on surface containing saliva after eight weeks. We observed low persistence of $C$. albicans in urine sample. This might be related to urine pH which avoids microbial survival for long periods which decreased in the presence of urine (Esteves et al., 2015). Blood showed greater yeast viability due to its high ability to provide a rich nutritional environment for microorganism (Esteves et al., 2015). This characteristic might allow yeast to persist long periods on abiotic surfaces as showed in our study.

Disinfectants recommended for hospital surfaces disinfection used in this study led to the expected effect on total growth inhibition, mainly sodium hypochlorite $2 \%$ and also on most surfaces in association of biological fluids with $70 \%$ alcohol. Our data corroborate with Pereira et al., 2014 who showed inhibition growth of C. albicans and non-albicans species after 30 seconds of sodium hypochlorite contact. No data were found in current scientific publications regarding the identification of yeast viability in association with alcohol 70\% then Peters et al., 2012 evaluated ethanol efficacy against microorganism biofilms. They found that incubation with ethanol $30 \%$ for 4 hours is sufficient to kill and completely inhibit $C$. albicans growth. Our data may has shown different pattern using alcohol 70\% due to absence of cleaning movements, which are recommended by ANVISA. However, even growth persistence using alcohol $70 \%$, we identified a decreasing cell counting in synthetic fabrics and, ceramic floor when compared with blood treatment. 


\section{Conclusion}

C. albicans strains significant persist viable on surfaces with higher moisture retention capacity. Use of $2 \%$ sodium hypochlorite may still be an effective control strategy for these yeasts in nosocomial environments. By using $70 \%$ alcohol in association of blood in the ceramic floor, egg crate foam mattress and synthetic fabric, the expected chemical agent action was not immediate. The understanding of these yeast persistence in hospital surfaces and fomites is essential for a better definition of protocols to control viability of $C$. albicans on abiotic surfaces, leading to infections prevention in healthcare environments.

We suggest controlling the spread of nosocomial pathogens through routine surface disinfection using $2 \%$ sodium hypochlorite, including to control cross-contamination caused by $C$. albicans. In addition, it is necessary to conduct further research on different surfaces with different sanitizers including nanoparticles in the search for hospital environments free of pathogenic microorganisms such as yeasts of the genus Candida.

\section{Acknowledgments}

The authors would like to thank the Foundation for Research Support of the State of São Paulo (process n 2017 / 22964-2) and also thank the University of Western Sao Paulo (project nº4114) for financial support.

\section{References}

Agência Nacional de Vigilância Sanitária. (2012) Segurança Do Paciente Em Serviços de Saúde: Limpeza e Desinfecção de Superfícies. ed. Anvisa. Anvisa.

Chmielarczyk, A., Pomorska-Wesołowska, M., Romaniszyn, D., \& Wójkowska-Mach, J. (2021). Healthcare-Associated Laboratory-Confirmed Bloodstream Infections - Species Diversity and Resistance Mechanisms, a Four-Year Retrospective Laboratory-Based Study in the South of Poland. International Journal of Environmental Research and Public Health, 18(5), 2785.

Hui, C., Zhou, X., Ren, B., \& Cheng, L. (2020) The Regulation of Hyphae Growth in Candida Albicans. Virulence 11:1, 337-48.

Enoch, D. A., Yang, H., Aliyu, S. H., \& Micallef, C. (2017) The Changing Epidemiology of Invasive Fungal Infections. In Human Fungal Pathogen Identifi Cation: Methods and Protocols. Thomas Lion (ed). Springer Science, pp. 17-65.

Esteves, D. C., Pereira, V. C., Souza, J. M., Keller, R., Simões, R. D., Eller, L. K. W., \& Rodrigues, M. V. P. (2015) Influence of Biological Fluids in Bacterial Viability on Different Hospital Surfaces and Fomites. American Journal of Infection Control, pp. 1-4.

Koca, O., Altoparlak, U., Ayyildiz, A., \& Kaynar, H. (2012) Persistence of Nosocomial Pathogens on Various Fabrics. The Eurasian Journal of Medicine 44, pp. 28-31.

Kramer, A., Schwebke, I., \& Kampf, G. (2006) How Long Do Nosocomial Pathogens Persist on Inanimate Surfaces? A Systematic Review. BMC Infectious Diseases 6:130.

Kumar, J., Eilertson, B., Cadnum, J. L., Whitlow, C. S., Jencson, A. L., Safdar, N., Krein, S. L. et al. (2019) Environmental Contamination with Candida Species in Multiple Hospitals Including a Tertiary Care Hospital with a Candida Auris Outbreak." Pathogens and Immunity 4:2, pp. 260-70.

Mccall, A. D., Pathirana, R. U., Prabhakar, A., Cullen, P. J., \& Edgerton, M. (2019) Candida albicans Biofilm Development Is Governed by Cooperative Attachment and Adhesion Maintenance Proteins. NPJ Biofilms and Microbiomes 5:21.

Mitchell, A., Spencer, M., \& Edmiston Jr., C. (2015) Role of Healthcare Apparel and Other Healthcare Textiles in the Transmission of Pathogens: A Review of the Literature. Journal of Hospital Infection, pp.1-8.

Neely, A. N., \& Orloff, M. M. (2001) Survival of Some Medically Important Fungi on Hospital Fabrics and Plastics. Journal of Clinical Microbiology 39:9, pp. 3360-61.

Pereira, S. S. P., Oliveira, H. M., Turrini, R. N. T., \& Lacerda, R. A. (2014) Disinfection with Sodium Hypochlorite in Hospital Environmental Surfaces in the Reduction of Contamination and Infection Prevention: A Systematic Review *. Rev Esc Enferm USP 49:4, pp. 675-81.

Peters, B. M., Ward, R. M., Rane, H. S., Lee, S. A., \& Noverr, M. C. et al. (2012) Efficacy of Ethanol against Candida albicans and Staphylococcus aureus Polymicrobial Biofilms." Antimicrobial Agents and Chemotherapy 57:1, pp. 74-82.

Piedrahita, C. T., Cadnum, J. L., Jencson, A. L., Shaikh, A. A., Ghannoum, M. A., \& Donskey, C. J. (2017) Environmental Surfaces in Healthcare Facilities Are a Potential Source for Transmission of Candida auris and Other Candida Species. Infection Control \& Hospital Epidemiology 38:9, pp. 23-25.

Ponde, N. O., Lortal, L., Ramage, G., Naglik, J. R., \& Richardson, J. P. (2021). Candida albicans biofilms and polymicrobial interactions. Critical Reviews in Microbiology, 47(1), 91-111. 
Research, Society and Development, v. 10, n. 5, e38010515049, 2021

(CC BY 4.0) | ISSN 2525-3409 | DOI: http://dx.doi.org/10.33448/rsd-v10i5.15049

Prada, I., Micó-Muñoz, P., Giner-Lluesma, T., Micó-Martínez, P., Collado-Castellano, N., \& Manzano-Saiz, A. (2019). Influence of microbiology on endodontic failure. Literature review. Medicina oral, patologia oral y cirugia bucal, 24(3), e364.

Santos, G. C. O., Vasconcelos, C. C., Lopes, A. J. O., Cartágenes, M. S. S., Filho, A. K. D. B., Nascimento, F. R. F., Ramos, R. M., et al. (2018) Candida Infections and Therapeutic Strategies: Mechanisms of Action for Traditional and Alternative Agents. Frontiers in Microbiology 9, pp. 1-23.

Traoré, O., Springthorpe, V. S., \& Sattar., S. A. (2002) A Quantitative Study of the Survival of Two Species of Candida on Porous and Non-Porous Environmental Surfaces and Hands. Journal of Applied Microbiology 92, pp. 549-55.

Ture, Z., \& Alp, E. (2018) Infection Control Measures to Prevent Hospital Transmission of Candida. Hospital Practice.

Viela, F., Mathelié-Guinlet, M., Viljoen, A., \& Dufrêne, Y. F. (2020). What makes bacterial pathogens so sticky? Molecular microbiology, 113(4), 683-690. 